\title{
A NEW FOSSIL SPONGE FROM THE ORDOVICIAN GARDEN CITY LIMESTONE OF SOUTHEASTERN IDAHO
}

\author{
J. Keith Rigby' and James K. Gilland'
}

Abstract.- The new choristid demosponge, Loganiella johnsoni, is described from the upper part of the Lower Ordovician Garden City Formation of southeastern Idaho. The new sponge is a relatively thin walled, low, subcylindrical form. The skeletal net is composed of tracts of curved rodlike spicules, but details have been lost on all specimens because of extensive silicification. Impressions, however, suggest a close relationship to the choristid Dystactospongia Miller, 1889.

Several specimens of a new sponge were collected from the Ordovician Garden City Limestone by Victor Church during a study of the Preston Quadrangle in southeastern Idaho in 1941. He was assisted by Chester O. Johnson of Gustavus Adolphus College during the study. Dr. Johnson kindly loaned us the collection of sponges he made at that time. A collection of sponges was also given to Utah State University by Mr. Church. These sponges were loaned to us by Dr. J. Stewart Williams and incorporated in this study.

The Garden City Formation was named for exposures in the Bear Lake region of northern Utah and southeastern Idaho by G. B. Richardson (1913: 407-408, 1914: 13-16) and includes the Lower Ordovician beds between the underlying Cambrian St. Charles Limestone and the overlying Swan Peak Quartzite. The formation is approximately 900 feet thick in the type section, which is approximately 15 miles east of the locality where the sponges were collected.

The Garden City Limestone was later restudied in detail by R. J. Ross, Jr. (1949, 1951). He described the fauna and zoned the formation utilizing the moderately abundant trilobites and other fossils and established an alphabetic zonation, parallel to that utilized by Hintze $(1951,1952)$ for equivalent beds of the Pogonip Group in western Utah and eastern Nevada.

The fossils were collected from E 1/2, NW 1/4, SE 1/4 Section 30, Township 16 South,
Range 42 East, in southern Franklin County, southern Idaho (Map 1). The locality is along the west face of Crab Ridge near the ridge crest, $.2 \mathrm{mi}$. north of the Utah-Idaho boundary. Crab Ridge is a prominent linear feature along the east side of the headwaters of Logan River.

Johnson (1962, pers. comm.) notes that there are no major outcrops in the wooded slope along the east side of Logan River valley near where the sponges were collected from talus fragments. There seems little question, however, that the material came from near the crest of Crab Ridge because of the location of the talus on the slope.

The sponges are silicified and some of the better specimens were etched free of matrix by dissolving the limestone in dilute acetic acid. Many small, spherical, Hindia-like sponges(?) were recovered in the residue, along with numerous conodonts. The conodonts were sent to Dr. Raymond L. Ethington of the Department of Geology, University of Missouri for identification and zonation. Ethington and Clark (Hintze 1977) have established a conodont zonation for the Pogonip Group in western Utah and eastern Nevada and have tied this to the trilobite zones of Hintze and Ross (1950). On the basis of the conodonts the sponges came from rocks of zone J to L (Ethington, 1977, pers. comm.).

Conodonts recovered from the matrix around the holotype (BYU 1090) include the following forms, identified by Ethington: 
?Drepanoistodus sp.

Microzarkodina aff. M. flabellus (Lindstrom)

"Scandodus" robustus Serpagli

Scolopodus gracilis Ethington and Clark

?Walliserodus aff. W. comptus (Branson \& Mehl)

New Genus A of Sweet, Ethington, \& Barnes, 1971

New Genus B of Sweet, Ethington, \& Barnes, 1971

Those conodonts recovered from matrix around the figured paratype (BYU 1091) include the following forms, identified by Ethington:

?Acodus sp.

?Drepanoistodus sp.

Microzarkodina aff. M. flabellus (Lindstrom)

Oistodus multicorrugatus Harris

Protopanderodus sp. s. f.

Scolopodus gracilis Ethington \& Clark

New Genus A of Sweet, Ethington, \& Barnes, 1971

New Genus B of Sweet, Ethington, \& Barnes, 1971

Ethington (1977, pers. comm.) notes that

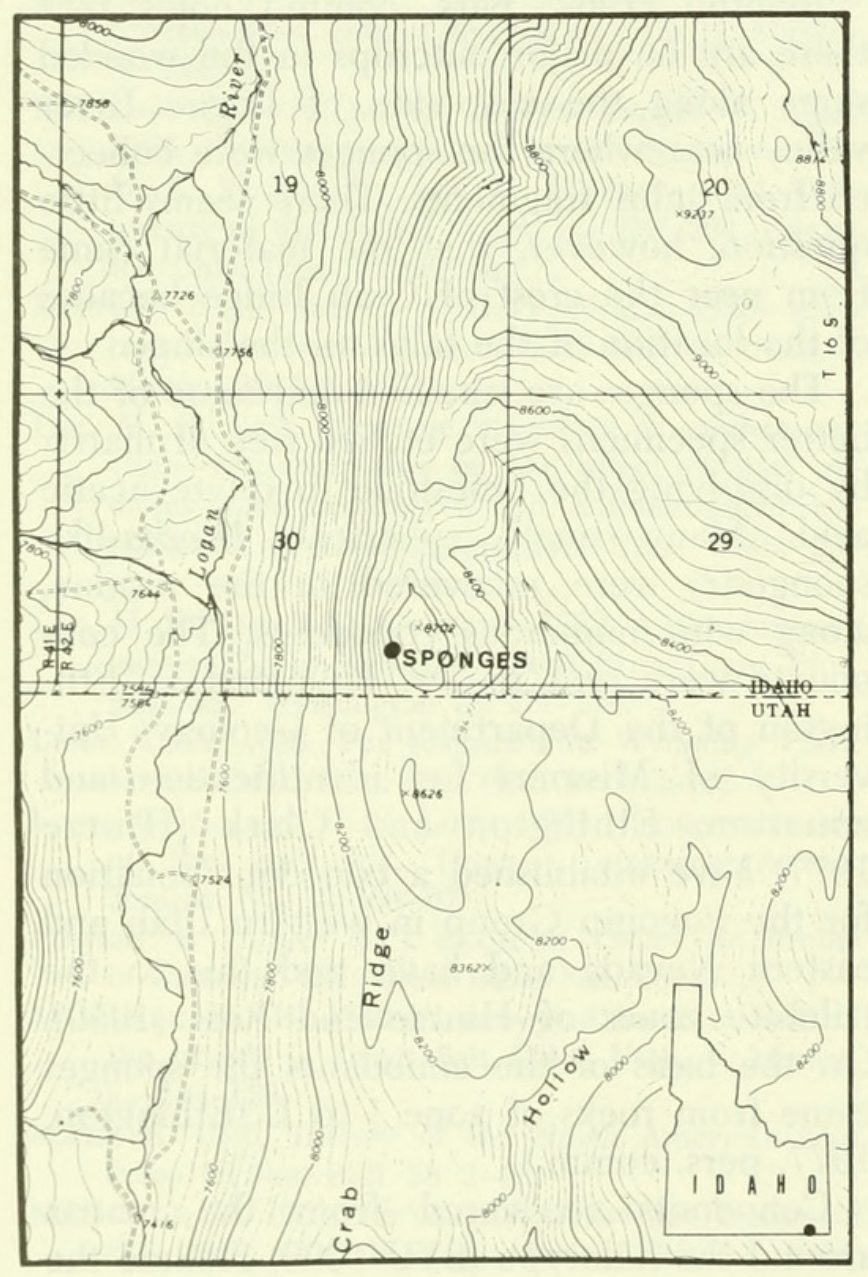

Map 1. Index map to the type locality of the new Ordovician sponge Loganiella johnsoni Rigby and Gilland. The sponge came from upper beds of the Garden City Formation, from talus blocks, on the east side of Logan River canyon.
"Oistodus multicorrugatus and Scolopodus gracilis have rather long ranges and are of little help for stratigraphic interpretation. Fortunately some of the forms are quite diagnostic. In particular, New Genus A, New Genus B, Microzarkodina aff. M. flabellum, and 'Scandodus' robustus occur together in the Wah Wah and Juab Formations. New Genus A and 'Scandodus' robustus are present in the basal Whiterockian (Orthidiella Zone) in the Monitor Range, central Nevada, which is the equivalent of Zone $\mathrm{L}$ in the Ibex area of western Utah. ... Clearly these conodonts represent a stratigraphic level near the top of the Canadian Series or near the bottom of the Whiterockian Stage. Until this series boundary between the Lower and Middle Ordovician has been defined more precisely, one cannot be more specific. In terms of the Hintze-Ross zonal scheme for shelly fossils they represent the general range of Zones J, K, and L."

\section{Systematic Paleontology \\ Class Demospongia Sollas, 1875 \\ Order Choristida Sollas, 1888 \\ Family uncertain \\ Loganiella, n. gen.}

Diagnosis.- Cylindrical to subcylindrical sponges with a flat base, a moderately thick wall, and a simple wide-open spongocoel. Relatively small canals feed radially, through the wall into the spongocoel. The skeletal net is composed of curved oxeas(?) that produce tracts with reticulate pattern that has a dominant radial structure.

Discussion.- At first glance, these forms appear similar to flat-crested Receptaculites, but the skeletal structure and the canal pattern is so distinctly dissimilar that the forms are clearly unrelated.

Perhaps the most closely related genus is Dystactospongia (Miller 1882: 42). In Miller's original description the spicule structure was poorly defined, but in a subsequently discovered specimen of Dystactospongia madisonenses Foerste, described by Rigby (1966), the spicule pattern is preserved. In this latter specimen, the skeletal net appears as a confused mass of 
fibrous spicules at first glance, but is composed of closely spaced spicules which intertwine-almost like a batch of spaghetti. Individual spicules line the canal openings, much as in the present specimens. Dystactospongia is a massive lobate, or digitate, to semiglobular form, however, in contrast to the simple, open, thin-walled, bowl shape of the present sponge. If our interpretation of the spicule pattern on the Idaho specimens is correct and the forms are related to Dystactospongia from the Ordovician of the midcontinent, Loganiella should be included in the Order Choristida in the Class Demospongia.

Eтymology.- The genus Loganiella is named after the Logan River, where the type material was recovered.

TYPE SPECIES.-Loganiella johnsoni.

\section{Loganiella johnsoni, n. sp.} Figs. 2-6

Description.- Bowl-shaped to cupshaped subcylindrical sponges (Fig. 1) with a flattened base and nearly vertical to slightly inclined walls that surround a simple, broad, open spongocoel. The base of the sponge is slightly concave to nearly flat, but with a rounded margin. From the rounded margin of the base, the walls extend vertically to slightly inclined inward for approximately $3 \mathrm{~cm}$ to the upper edge of the fragment.

The holotype (BYU 1090; Figs. 3, 5, 6) is nearly circular, when viewed from above, and has a maximum diameter of $72 \mathrm{~mm}$. The base is slightly warped, possibly during growth because the spicule net apparently is solidly fused and the sponges appear to show little distortion. Wall thickness is moderately uniform, ranging from $3.7 \mathrm{~mm}$ at the thin oscular(?) margin up to a maximum of $4.5 \mathrm{~mm}$ where the flat base curves upward into the subcylindrical wall.

A paratype (BYU 1091; Figs. 2, 4) is of the same general shape and has a maximum diameter of $70 \mathrm{~mm}$ and is from 20 to 22 $\mathrm{mm}$ high. The base of the sponge is approximately $10 \mathrm{~mm}$ thick. The wall thickens to a maximum of $15 \mathrm{~mm}$ at the lower-most margin of the spongocoel but then thins to only 5 to $6 \mathrm{~mm}$ at the upper edge of the preserved fragment. In the paratype a moderately long section of what is considered to be the upper oscular rim is preserved. It has a rounded, although somewhat channeled, upper surface. The wall structure shows well completely around the upper edge. Where the wall has been broken and irregularly silicified the radial canal pattern shows moderately well.

The canal pattern shows best in the holotype where four different sizes of openings are present. The largest of these occur on the exterior of the base and they are particularly well defined in an area newly etched free of matrix. These large canals are circular to elliptical. They are particularly elliptical where two canals appear to converge to form one circular opening within the interior. Circular single canals range from $0.20 \mathrm{~mm}$ to $0.6 \mathrm{~mm}$ in diameter. These canals are separated by relatively thick skeletal tracts that range from 0.3 to $1.5 \mathrm{~mm}$ across. This particular canal series is spaced moderately irregularly over the surface, but in some areas occurs in an almost rectangular pattern. In a characteristic area $5 \mathrm{~mm}$ square there are from 20 to 25 of the larger canal openings. Where the pattern is moderately regular or linear they are spaced approximately $1 \mathrm{~mm}$ apart. There may be five or six of the larger canal openings per $5 \mathrm{~mm}$, as measured along any one single series.

A second, smaller series of canals ranges from 0.15 to $0.30 \mathrm{~mm}$ in diameter. These occur irregularly within the skeletal tracts and appear to parallel or possibly converge with the larger canal openings in the interior of the wall. Where best preserved, these small canals are spaced from 0.4 to $0.6 \mathrm{~mm}$ apart along an individual skeletal tract but, in general, they occur in the dense skeletal net. Some of these openings are irregular and may be produced, in part, by irregularities of silicification. Others, however, are sufficiently circular and so well defined that they must indicate original openings in the net of the sponge. These canals are spaced from 0.1 to $0.2 \mathrm{~mm}$ apart in cross sections 

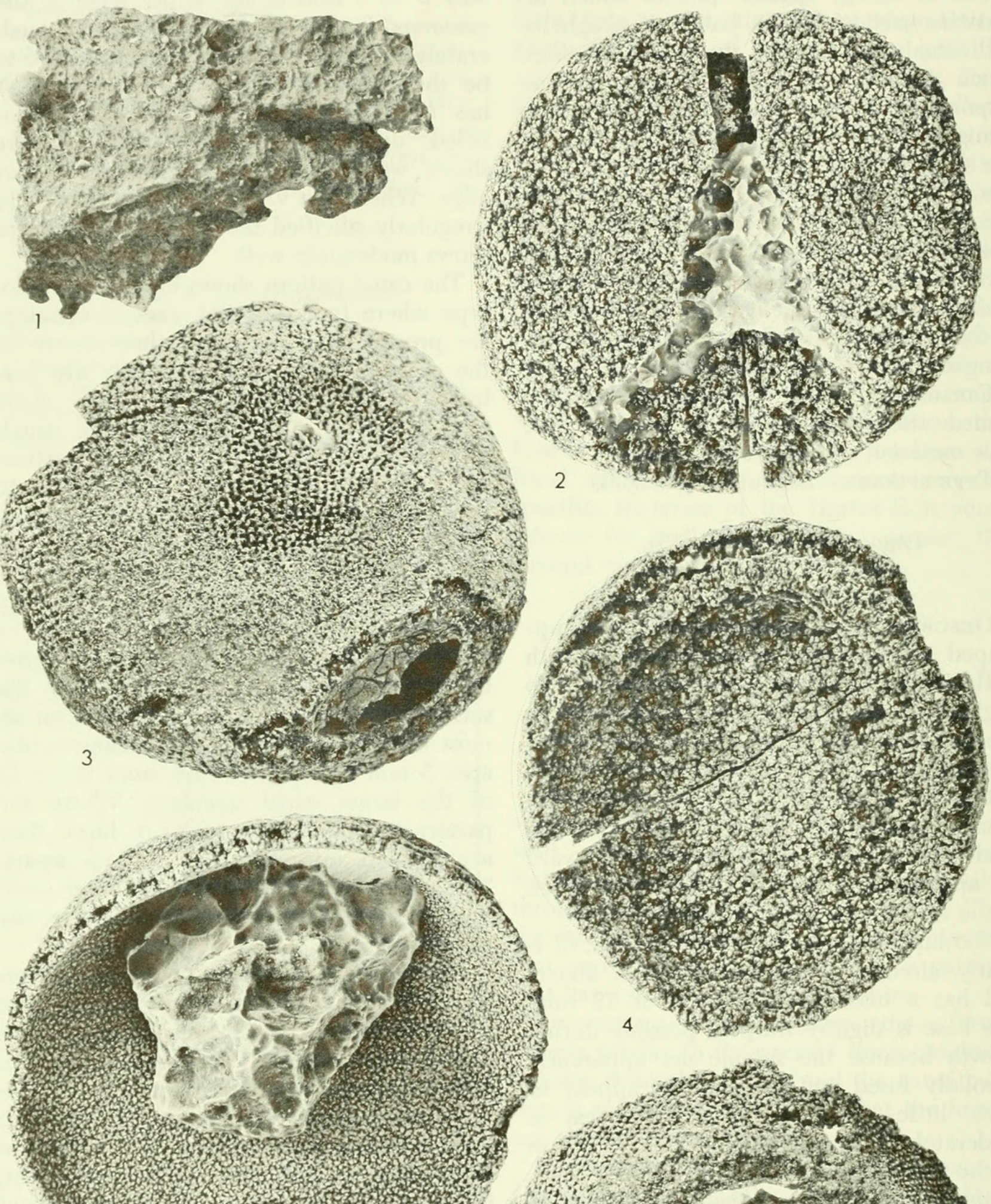
. 3 . 1. Y. 5.6.

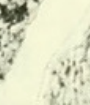


through the wall and, like the large canal series, appear to pass directly through the wall and to be almost straight.

The inner surface of the spongocoel is somewhat more irregular than the exterior and the canals there are poorly defined. Circular canals ranging from 0.25 to 0.6 $\mathrm{mm}$ in diameter occur on the silicified or encrusted interior wall. Most canal openings here range from 0.25 to $0.30 \mathrm{~mm}$ across, are terminations to the straight radiating canal series, and connect to the larger ostia on the exterior. These spongocoel openings, in general, are separated by skeletal tracts from 0.4 to $0.6 \mathrm{~mm}$ across. These tracts, like those on the exterior, have rounded cross sections so that the diameter of the canal openings flare at the immediate spongocoel surface but narrow a few tenths of a millimeter into the wall from the spongocoel margin.

Smaller openings, from 0.15 to $0.3 \mathrm{~mm}$ across, are also common and may represent inner termination of some of the large radiating canals.

The spongocoel margin has a somewhat frosted or rounded appearance, in contrast to the much more sharply defined canals and skeletal tracts of the exterior. The gastral or interior surface of the wall is irregularly porous and there is practically no pattern of canal placement, such as the linear pattern seen on the exterior.

Because of silicification, spicules in the interior of the tracts are not preserved, but impressions of the spicules are evident on the exterior of a few tracts, particularly on the spongocoel margin. They are curved to moderately straight rodlike spicules which appear to be diactines. It is impossible to tell in this preservation whether these are rhizoclone spicules with a smooth exterior facing toward the canals or whether they are oxeas or simple curved spicules as in Dystactospongia. These spicules are from 0.02 to $0.035 \mathrm{~mm}$ in diameter and up to $0.25 \mathrm{~mm}$ long, although on none can the total length be recognized because the tips are either broken or lost in the ropy fabric. Spicules are curved to outline the circular canals and lie tangential to the main fibers. On some tracts, where the spicules show particularly well, there are from 10 to 15 spicules coating the exterior. This would suggest that individual tracts may have as many as 50 to 75 spicules in a single cross section. The spicules generally are elongate, parallel to the long dimensions of the somewhat reticulate mesh. In the crossconnecting bars, for example, they are tangential to the spongocoel wall and crossconnect the tracts which are extending directly through the sponge wall. The spicule pattern is less clearly preserved on the exterior-a few spicules' impressions here and there-and the generally ropy appearance of the tracts is poorly expressed.

Etrmology.- The species is named in honor of Dr. Chester O. Johnson, who recognized the sponge origin of the material and made most of the collection available.

Type materials and ocCURREnCE.- The

Figs. 1-6. Fossil sponges from the Garden City Limestone of southeastern Idaho: 1. Small spherical Hindia(?) associated with the holotype of Loganiella, from the Garden City Limestone, Logan River locality; 87 percent of natural size.

Figs. 2-6. Loganiella johnsoni. 2, 4, Paratype, BYU 1091. 2, Flat, coarsely silicified base of the paratype with some calcareous matrix in the sponge wall. 4, View from above into the simple spongocoel of the coarsely silicified paratype showing the moderately thick walls of this particular specimen. 3, 5, 6, Holotype BYU 1090 . 3, View of the flat base of the holotype showing the somewhat rectangularly spaced skeletal tracts of the sponge. The opening at the lower right is an artifact of preservation. Small light triangular area in the upper right center is a residum of matrix. Spicules show under the microscope near the base of this remnant. 5, View down into the flat bottom of the spongocoel of the holotype, here partially encrusted by matrix. The thin wall of this specimen shows above, in the wall fragment in the upper part of the specimen. The distinctly nonpatterned openings of the canals on the interior of the sponge contrast sharply with the distribution seen in the basal part of the exterior. The artificial opening through the sponge wall here is at the top of the specimen. 6, Side view showing the characteristic flat base, rounded margins, subcylindrical to broadly conical walls, and the moderate regularity of canal spacing on the upper flanks of the sponge; 87 percent of natural size. 
sponges are known, at present, only from the upper part of the Garden City Formation, in rocks of zone $\mathrm{J}$ to $\mathrm{L}$, in southern Idaho. Holotype, BYU 1090, and paratype, BYU 1091.

\section{Literature Cited}

Hintze, L. F. 1951. Lower Ordovician detailed stratigraphic sections for western Utah. Utah Geol. Min. Survey Bull. 39: 100.

1952. Lower Ordovician trilobites from western Utah and eastern Nevada. Utah Geol. Min. Survey Bull. 48: 249.

Miller, S. A. 1882. Description of two new genera and eight new species of fossils from the Hudson
River Group, with remarks upon others: J. Cincinnati Soc. Nat. Hist. 5: 34-44.

Richardson, G. B. 1913. The Paleozoic section in northern Utah. Amer. J. Sci. 36 (4): 406-416.

1941. Geology and mineral resources of the Randolph quadrangle, Utah-Wyoming. U.S. Geol. Survey Bull. 923: 55.

Rigby, J. K. 1966. Microstructure and classification of an Ordovician sponge, Dystactospongia madisonensis Foerste from Indiana. J. Paleont. 40: $1127-1130$

Ross, R. J. JR. 1949. Stratigraphy and trilobite faunal zones of the Garden City Formation, northeastern Utah. Amer. J. Sci. 247: 472-491.

1951. Stratigraphy of the Garden City Formation in northeastern Utah and its trilobite faunas. Yale Peabody Mus. Bull. 6: 161. 


\section{$2 \mathrm{BHL}$ Biodiversity Heritage Library}

1977. "A new fossil sponge from the Ordovician Garden City limestone of southeastern Idaho." The Great Basin naturalist 37, 475-480.

https://doi.org/10.5962/bhl.part.10531.

View This Item Online: https://www.biodiversitylibrary.org/item/35776

DOI: https://doi.org/10.5962/bhl.part.10531

Permalink: https://www.biodiversitylibrary.org/partpdf/10531

\section{Holding Institution}

Harvard University, Museum of Comparative Zoology, Ernst Mayr Library

\section{Sponsored by}

Harvard University, Museum of Comparative Zoology, Ernst Mayr Library

\section{Copyright \& Reuse}

Copyright Status: In copyright. Digitized with the permission of the rights holder.

License: http://creativecommons.org/licenses/by-nc-sa/3.0/

Rights: https://biodiversitylibrary.org/permissions

This document was created from content at the Biodiversity Heritage Library, the world's largest open access digital library for biodiversity literature and archives. Visit BHL at https://www.biodiversitylibrary.org. 